\author{
Maria M. Rachwal \\ Małopolskie Forum Przedsiębiorczości \\ Tomasz Rachwal \\ Zakład Przedsiębiorczości i Gospodarki Przestrzennej \\ Instytut Geografii \\ Akademia Pedagogiczna, Kraków
}

\title{
Wartości moralne podstawą prawdziwego sukcesu menedżera
}

Wartości są w życiu każdego człowieka jak kompas moralny, który zawsze wskazuje właściwą drogę. Jeżeli wiemy, jak według nich żyć, nie zagubimy się, nie popadniemy w dezorientację, nie oszukają nas sprzeczne sygnały, bo zasady etyczne nigdy się nie zmieniają, przez całe życie wskazują właściwy kierunek, ten, w którym należy dążyć. Odnoszą się one do każdego czasu i miejsca. Zarządzanie oparte na wartościach moralnych opiera się na założeniu, że menedżer nie może tych zasad bezkarnie łamać, gdyż bez względu na to, czy w nie wierzy, czy nie, doświadczenie historyczne dowodzi ich prawdziwości. Historia uczy bowiem, że powodzenie człowieka, poszczególnych społeczeństw i całych cywilizacji zależy od stopnia, w jakim stosują się one do właściwych zasad. U podstaw katastrof ekonomicznych, konfliktów kulturowych, upadku wielkich cywilizacji, rewolucji politycznych i wojen leży właśnie pogwałcenie zasad moralnych. W niniejszych rozważaniach przyjmujemy więc - za S. Coveyem (2004) - założenie, że działanie jednostek jest bardziej efektywne, a organizacje działają o wiele skuteczniej i stają się coraz silniejsze, jeśli kierują się sprawdzonymi zasadami moralnymi. Pogląd taki jest coraz powszechniej i dobitniej akcentowany w literaturze dotyczacej zarządzania. Trafnie to ujmuje m.in. filozofia Walta Disneya, która zakłada, że „kiedy wartości są jasne, decyzje są łatwe”. Twórca jednej z największych firm świata był przekonany, że ,jeśli firma ma wspiąć się na wyżyny, nie może się godzić na żaden kompromis w kwestii wartości”' (Capodagli, Jackson 2002). Dlatego prawdziwy sukces menedżera zależy od zarządzania poprzez wartości. Takie podejście jest przeciwieństwem bardzo rozpowszechnionego, szczególnie w Polsce w latach transformacji gospodarczej, tzw. zarządzania pieczarkowego, w myśl zasady: „Trzymaj ludzi w ciemności, dawaj im nawóz, a gdy w pełni dojrzeją, zetnij głowy i wsadź do słoika" (Covey 2004). Zarządzania, w którym złem jest dać się przyłapać, a nie takiego, w którym złem jest postępowanie niezgodne z zasadami etycznymi.

Celem artykułu jest zwrócenie uwagi na wartości, które są podstawą prawdziwego sukcesu menedżera. Chociaż może to się wydać zaskakujące, celowe jest chyba użycie sformułowania „prawdziwy sukces”, gdyż samo słowo „sukces”, czy to w stosunku do menedżera, czy do firmy, bardzo często utożsamiane jest wyłącznie z sukcesem finansowym, przejawiającym się wzrostem dochodów osobistych i awansem lub wzrostem przychodów i zysków firmy. Sukces pojmowany w ten sposób nie daje pełnej satysfakcji i jest bardzo często nietrwały. Zauważył to człowiek sukcesu opartego na wartościach, Jon Huntsman, który w bestsellerze Zwycięzcy nie oszukuja napisał: „obecny klimat biznesu, w którym zwycięzca bierze wszystko, kusi, by pokonać trudną drogę na skróty i kłamać. Jednak cwaniacy, oszuści, sportowcy stosujący niedozwolone chwyty spadają z firmamentu tak szybko, jak się na nim znaleźli. A kiedy spadają, uderzają 
o twarde dno. Ból jest silny i twardy. Zarząd Enronu szukał wymówek od samego początku afery. Tak samo było w przypadku skandalu księgowego Tyco. Jednak rynek nie uwierzył w fałszywe zapewnienia i nie zaakceptował nielegalnych praktyk" (Huntsman 2005). Prawdziwy sukces bowiem, oparty na wartościach moralnych, osiagają ci, którzy mają umiejętności i odwagę, ale zarazem są uczciwi i przyzwoici. Osoby takie żyją uniwersalnymi wartościami etycznymi, a nie tylko celem finansowym, który nie może usprawiedliwiać nieetycznych środków prowadzących do niego. Kierowanie się zasadami powoduje, że menedżerowie prawdziwego sukcesu są szczęśliwi zarówno na płaszczyźnie prywatnej, jak i zawodowej, znajdują sens w życiu, wiedza, co w ich życiu jest najważniejsze, dzięki czemu potrafią łączyć satysfakcjonujące życie rodzinne i szczęście osobiste z życiem zawodowym. Ponieważ w firmie tworzą atmosferę zaufania, do pracy idą z radością, nie obawiając się zawiści. Ważniejsze są dla nich wartości niż stanowiska i pieniądze, dzięki czemu żyją w zgodzie z własnym sumieniem. Ich postawa jest optymistyczna, pozytywna i podnosząca na duchu. Są pełni entuzjazmu, nadziei i wiary.

Pozostają więc najważniejsze pytania: Jakimi wartościami moralnymi powinien kierować się menedżer? Stosowanie jakich zasad decyduje o prawdziwym sukcesie? Spośród wielu zasad moralnych chcemy zwrócić uwagę na te, które naszym zdaniem są w procesie zarządzania najważniejsze. Są to jednocześnie wartości, o których najwięksi menedżerowie mówiąjako o warunku prawdziwego sukcesu i których znaczenie potwierdzają badania naukowe.

Pierwsza z nich to uczciwość. Uczciwość w każdym względzie, na każdym kroku, mimo że „ludzie często usprawiedliwiają kłamstwa, oszustwa czy kradzieże, mówiąc, że byli pod presją albo »przecież każdy tak robi«. Niektórzy pewnie powiedzą, że muszą kraść czy oszukiwać, bo nie mają innego wyjścia. Takie wymówki brzmią lepiej niż prawdziwe przyczyny zejścia na manowce: arogancja, dążenie do władzy, chciwość, brak kręgosłupa moralnego. (...) Wymawiając się i podając fałszywe uzasadnienia wiemy, że postępujemy źle. Osiagnięcie sukcesu czy dostanie się na szczyt za wszelką cenę to z definicji cel niemoralny" (Hunstman 2004). Słowa te wypowiedział cytowany już Jon Huntsman, człowiek, który zaczynał w 1970 r. od zera, a zbudował największą firmę rodzinną w Stanach Zjednoczonych i stał się jednym z najbogatszych Amerykanów.

Chodzi zatem o uczciwość na każdym kroku. Począwszy od oczywistej uczciwości w sprawach finansowych, czyli o stosowanie się do zwyczajnego „nie kradnij”, poprzez uczciwość w stosunku do podwładnych i przełożonych, a także w stosunku do kontrahentów i klientów. Jak się wydaje, najbardziej dotkliwa w Polsce w czasach współczesnych jest właśnie nieuczciwość w elementarnych relacjach między menedżerem-pracodawcą a pracownikiem. Często nieuczciwość zaczyna się już od samego procesu rekrutacji; jakże często kandydaci do pracy są mamieni obietnicami jej otrzymania, ileż razy nie doczekują się obiecanego telefonu o wynikach rozmowy kwalifikacyjnej, ile razy przedstawia im się do podpisania umowy o pracę, których warunki znacznie różnią się od ustalonych podczas rozmowy kwalifikacyjnej lub bez ogródek proponuje pracę „na czarno”. Dalej, już podczas wykonywania pracy: jak często nie płaci się za nadgodziny, fałszuje listy obecności, nie udziela urlopów, łamie podstawowe zasady bezpieczeństwa i higieny pracy, szczególnie w stosunku do kobiet w ciąży, czasem wręcz łamie elementarne zasady przyzwoitości, np. nie wypuszczając pracowników do toalety. Przypadki nagłośnione w latach 2004 i 2005 przez media pod wpływem informacji o nieetycznym i niezgodnym z prawem traktowaniu pracowników niektórych wielkich sieci handlowych, wcale nie są odosobnione. Łamanie podstawowych praw pracowniczych potwierdzają liczne raporty Państwowej Inspekcji Pracy, w wyniku których nie tylko wydano decyzje o usunięciu naruszeń czy wyznaczono kary grzywny, 
ale także skierowano zawiadomienia do prokuratury o podejrzeniu popełnienia przestępstwa ${ }^{1}$. Potwierdzają to także wypowiedzi różnych osób - kandydatów do pracy. Jakże często kandydaci, słysząc o obowiązujących warunkach pracy w firmie, cieszyli się, że w ciagu dnia będą mogli mieć przerwę, bo w ich dotychczasowym miejscu pracy było to niemożliwe, niezależnie od liczby spędzonych w nim godzin. Czasem żenujące było nawet słuchanie opowieści o traktowaniu pracowników w poprzednim miejscu pracy (notabene wypowiedzi te łamały jedną z zasad prowadzenia rozmów kwalifikacyjnych, podczas których nie powinno się w złym świetle przedstawiać poprzedniego pracodawcy - świadczy to jednak o wyjątkowej determinacji osób, które tak były traktowane). Warto więc się zastanowić, jak czuje się człowiek, który tak traktuje pracowników. Czy ma satysfakcję, gdy osiaga nawet bardzo korzystny wynik finansowy takimi środkami? Czy może liczyć na lojalność pracowników? Czy jego podwładny będzie z chęcią wykonywał swoją pracę, z zadowoleniem obsługiwał klientów? Jest oczywiste, że przy pierwszej nadarzającej się okazji najlepsi odejdą. W firmie, w której z powodu złego traktowania traci się najlepszych pracowników, sukces finansowy jest możliwy, ale z reguły krótkotrwały i szybko może okazać się ekonomiczną katastrofą. Ujął to trafnie James C. Collins (2003): „,Ci, którzy tworzą wielkie przedsiębiorstwa, zdają sobie sprawę, że wąskim gardłem rozwoju firmy mogą okazać się nie rynki, technologie, konkurencja czy produkty. Ważniejsza od tego wszystkiego jest zdolność firmy do zatrudniania i utrzymywania odpowiedniej ilości właściwych ludzi”.

Uczciwość to także sumienne wykonywanie swoich obowiązków. Często menedżerowie, niezależnie od szczebla, jaki zajmują w hierarchii firmy, nie zdają sobie sprawy, że nierzetelne wykonywanie obowiązków w myśl starej zasady „czy się stoi, czy się leży, pensja i tak się należy”, okradają nie tylko pracodawców, którzy płacą im za pracę, ale także kolegów i współpracowników, którzy muszą za nich wykonywać zadania. W ten sposób dają też zły przykład swoim podwładnym, którzy wzorują się na takim podejściu do pracy.

Podobnie jest z uczciwością w stosunku do kontrahentów i partnerów w biznesie. Jakże często np. podczas negocjacji biznesowej stosuje się nieuczciwe techniki manipulacyjne ${ }^{2}$. Warto się zastanowić, czy w ten sposób można zbudować trwałe relacje biznesowe, zawrzeć korzystny, długotrwały kontrakt. Przecież w sytuacji, gdy taka manipulacja zostanie zdemaskowana, najczęściej następuje całkowite fiasko negocjacji, niezależnie od merytorycznych przesłanek. Partner oszukany w negocjacjach nie będzie chciał budować trwałych związków biznesowych z osobą postępującą nieuczciwie, nawet jeśli wydaje się, że jest szansa na wynegocjowanie korzystnych warunków. Jednym słowem, takie nieuczciwe techniki mogą być skuteczne co najwyżej w pojedynczych transakcjach, które nie decydują o trwałym sukcesie firmy. Sukces firmy zależy przecież od stałych, lojalnych klientów. Uczciwy menedżer ma jeszcze osobistą korzyść z etycznego postępowania w biznesie - trafnie to ujął cytowany już multimiliarder Jon Huntsman (2004): „Dzięki uczciwemu graniu nie będziesz musiał pamiętać, co powiedziałeś poprzedniego dnia”.

\footnotetext{
${ }^{1}$ Por. np. Sprawozdanie Głównego Inspektora Pracy z działalności Państwowej Inspekcji Pracy w 2004 r.; Efekty działań Państwowej Inspekcji Pracy w sklepach sieci Biedronka; Wyniki kontroli sklepów Kaufland Polska sp. z o.o.; Przestrzeganie przepisów prawa pracy w supermarketach, hipermarketach $i$ sklepach dyskontowych w latach 1999-2005 r. - raport. Skargi dotyczace równego traktowania w pracy oraz mobbingu w 2004 r. - raport (www.pip.gov.pl).

${ }^{2} \mathrm{~W}$ niektórych podręcznikach, także w podręcznikach szkolnych do podstaw przedsiębiorczości, techniki o charakterze manipulacyjnym nazywane są często „technikami negocjacji”, a nie „technikami manipulacji podczas negocjacji”, co należy uznać za zjawisko bardzo niepożądane.
} 
Kolejna wartość istotna dla menedżera prawdziwego sukcesu to prawdomówność. Czyny takich menedżerów są zgodne $\mathrm{z}$ ich słowami. Nie obiecują oni gruszek na wierzbie, np. swoim podwładnym awansu czy podwyżki, które w bliżej określonej przyszłości nie mogą być zrealizowane. Nie ukrywają kłopotów firmy, np. konieczności redukcji zatrudnienia, lecz mówiąc prawdę, starają się znaleźć najlepsze rozwiązanie sytuacji, zgodnie z zasadą, że lepiej powiedzieć nawet najgorszą prawdę niż nieprawdę. Zwrócił na to uwagę James C. Collins w cytowanej już pozycji Od dobrego do wielkiego (2003): „Ludzie najszybciej tracą motywację jeśli dajesz im fałszywą nadzieję, która okazuje się niemożliwa do spełnienia".

Kiedy menedżer mówi prawdę, pracownicy obdarzają go zaufaniem i odwzajemnią się tym samym, mówiąc prawdę o sytuacji w firmie. Szczególnie jeśli są pracownikami tzw. pierwszej linii, to ich relacje, spostrzeżenia czy uwagi mogą być bardzo ważne dla powodzenia firmy. Pracownik znający przyczyny niepowodzenia w jakimś obszarze działania firmy, który nie ufa menedżerowi, najczęściej nie mówi mu prawdy, bo boi się, że zostanie za te niepowodzenia obarczony winą. Dzięki atmosferze prawdy menedżer sukcesu jako pierwszy dowiaduje się o problemach firmy i jest w stanie tym problemom przeciwdziałać. Bo tylko stawienie czoła nawet najbardziej wrogim faktom otaczającej rzeczywistości prowadzi do zwycięstwa. Okłamywanie siebie i innych prowadzi do rychłej katastrofy.

Kolejne wartości istotne dla menedżera prawdziwego sukcesu to lojalność, czyli uczciwość, wierność, prawość i oddanie innym. Szczególnie wobec nieobecnych. Lojalność jest warunkiem dobrej współpracy. To także niepodważanie czyjegoś autorytetu i szanowanie go jako osoby. Lojalny menedżer tworzy atmosferę zaufania i szacunku. Umożliwiają to otwarta komunikacja i skupienie się na rozwiązywaniu problemów i tworzeniu przyszłości firmy. Brak lojalności zaś wywołuje atmosferę walki, plotkarstwa i niepewności, która prowadzi do upadku morale w firmie, odchodzenia najlepszych pracowników i braku koncentracji na najważniejszych sprawach.

Skromność i pokora. Menedżerowie prawdziwego sukcesu nie przypisują sobie sukcesu, upatrując go także w sprzyjających okolicznościach, szczęściu, ale jednocześnie tylko w sobie szukają przyczyn porażki, nie obwiniając o nią otoczenia czy bliżej nieokreślonego pecha (Collins 2003). Ich dążenia i decyzje są skierowane na rozwój firmy, a nie na własne korzyści i własne ego, np. własny prestiż, uznanie i podziw innych. Tacy menedżerowie poszukują godnych następców, gdyż najważniejsze jest dla nich dobro firmy, a nie wykazanie, że firma dobrze prosperowała jedynie w czasie ich zarządzania. Prawdziwe przywództwo jest bowiem odwrotnie proporcjonalne do wykorzystania władzy.

Ważną wartością jest także dzielenie się z innymi. Chodzi nie tylko o dzielenie się zyskami firmy, np. wypłacanie premii czy udziałów w zysku firmy, co zwiększa lojalność pracowników wobec firmy i ich zaangażowanie w pracę, ale także dzielenie się sukcesami. Pracownicy, których szef wskazuje jako głównych autorów sukcesu, starają się pracować jeszcze wydajniej i jeszcze lepiej. Wielcy menedżerowie, jak Stephen Covey czy Jon Huntsman, mówią również o anonimowej pomocy innym: ,Zawsze gdy w anonimowy sposób pomagamy innym, wzrasta nasze poczucie wartości i szacunek dla samego siebie. Co więcej, doceniamy wartość innych ludzi, służąc im bez rozgłosu i bez oczekiwania na nagrodę. Bezinteresowna pomoc zawsze była jedną z najskuteczniejszych metod wywierania wpływu" (Huntsman 2005).

Inną wartością istotną dla menedżera prawdziwego sukcesu jest pracowitość. Czasami można coś osiagnąć lawirowaniem, kombinowaniem, zrzucaniem swojej pracy na innych, ale kiedy naprawdę w firmie pojawiają się kłopoty, niepracowitemu menedżerowi brakuje narzędzi, żeby im przeciwdziałać. Przecież do tej pory zrzucał odpowiedzialną pracę na inne osoby, a teraz może mu zabrakną́ tych osób, które - jako najlepsi pracownicy - zapewne opuściły już firmę. Pracowitego menedżera cechuje również ciągłe poszerzanie wiedzy i zdobywanie nowych 
umiejętności. Trafnie to ujął Stephen Covey w Zasadach skutecznego przywództwa: „Ludzie postępujący według zasad nieustannie się doskonalą dzięki zdobywaniu doświadczenia. Czytają, biorą udział w szkoleniach i zajęciach poszerzających ich informacje, słuchają innych, chłoną wiedzę za pomocą uszu i oczu. Są ciekawi, zawsze zadają pytania. Nieustannie poszerzają swoje kompetencje, zdolność do wykonywania zadań, rozwijają nowe umiejętności i zainteresowania. Odkrywają że im więcej wiedza, tym bardziej są świadomi swojej niewiedzy. Większość energii zużywanej na naukę i rozwój pozostaje w nich samych i sama sobą się żywi” (Covey 2004).

Kolejną istotną wartością jest wspólpraca, czy nawet - według Coveya (2004) - coś więcej: efekt synergii. Całość jest bowiem większa niż suma jej części. Jeden plus jeden równa się trzy i więcej. Dzięki uczciwemu postępowaniu menedżer tworzy atmosferę zaufania i otwartości. W takiej atmosferze ludzie pracują na zasadach współzależności, są zdolni do realizowania potencjału twórczego, do udoskonaleń i innowacji dających więcej korzyści niż suma ich indywidualnych możliwości wykorzystywanych oddzielnie. W atmosferze prawdy i lojalności nikt nie jest nastawiony na ochronę swojej pozycji, ale wszyscy szukają najlepszych rozwiązań. Ze współpracą wiąże się życzliwość, troskliwość i otwartość dla innych. Autokratyczny czy czasem wręcz agresywny styl zarządzania pozbawia menedżera tak istotnej w każdym biznesie informacji zwrotnej z niższych szczebli organizacji. Pracownicy, wobec których stosuje się przymus jako podstawową formę motywacji, reagują niezadowoleniem lub wręcz agresją i nigdy nie zaangażują się w pełni w wykonywane zadania. Menedżer prawdziwego sukcesu, zamiast autokratycznych rozkazów, wysyła pozytywną energię, która przyciaga i wzmacnia mniejsze pola pozytywnej energii innych.

Wreszcie wiara w innych. Menedżer prawdziwego sukcesu wierzy w każdego, także w szeregowych pracowników tzw. pierwszej linii, którzy bardzo często wiedzą więcej o problemach firmy niż zarząd. Wiara w innych to podstawa motywacji (a nie, jak się powszechnie sądzi-pieniądze), to wielka siła sprawcza. Ludzie są tacy, jakie są oczekiwania wobec nich. A zatem menedżer sukcesu musi uwierzyć w ukryty potencjał swojego pracownika, a ten da z siebie wszystko co najlepsze, aby zrealizować zadanie. Menedżerowie prawdziwego sukcesu wierzący w innych ludzi nie poszukują winnych porażek czy chwilowych kłopotów, lecz starają się zrozumieć ich przyczyny w celu wyciagnięcia wniosków na przyszłość, aby takie sytuacje wyeliminować.

Ostatnią wartością menedżera prawdziwego sukcesu, na którą chcemy zwrócić uwagę, jest odwaga. Odwaga, która nie polega na nieodczuwaniu strachu, lecz „,na uznaniu, że coś jest ważniejsze niż lęk" (Covey 2005). Dlatego menedżer prawdziwego sukcesu nie boi się podejmowania odważnych decyzji, np. o rozpoczęciu realizacji projektu, które może, ale nie musi okazać się ,strzałem w dziesiątkę”. Ale dzięki temu odwaga staje się źródłem innowacji produktowych, technologicznych bądź organizacyjnych, i czynnikiem zwiększającym konkurencyjność firmy na rynku. Odwaga menedżera prawdziwego sukcesu polega także na umiejętności przeciwstawienia się naciskom zewnętrznym, nawet swoich przełożonych. Taki menedżer nie postapi wbrew swojemu sumieniu i uznawanym przez siebie wartościom, nie będzie akceptował działań niezgodnych z normami prawnymi i moralnymi mimo poleceń czy nacisków płynących „,z góry”, od przełożonego bądź pracodawcy.

Dzięki zarządzaniu zgodnie z wartościami menedżer może cieszyć się prawdziwym sukcesem. Także bardzo często sukcesem finansowym. Lektura biografii wielkich menedżerów sukcesu wskazuje, że postępując zgodnie z zasadami etycznymi, osiagnęli oni szczęście i satysfakcję w życiu, a także zarobili dużo pieniędzy. Ale pieniądze nie są tu najważniejsze, są jakby obok, „przy okazji”. Stan szczęścia tych osób wynika nie z faktu, że ich firmy generują coraz większe zyski, a oni sami stają się multimiliarderami, ale z tego, że traktują oni swoje życie jako misję, a nie jako karierę. Misję służenia innym ludziom zgodnie z wartościami moralnymi, niezależnie od przeciwieństw losu i reakcji otoczenia. 
Na potrzebę takiego podejścia do sukcesu zwrócił też uwagę jeden z największych autorytetów w dziejach ludzkości, papież Jan Paweł II, w orędziu na światowy Dzień Pokoju 2000 r.: „Pragnę zaapelować w tym miejscu do ekonomistów oraz działaczy gospodarczych i polityków, aby uświadomili sobie, że praktyka ekonomiczna oraz działania polityczne w tym sektorze muszą mieć na celu dobro każdego człowieka i całego człowieka. Nakazuje to nie tylko etyka, ale także zdrowa ekonomia. Doświadczenie bowiem zdaje się wskazywać, że sukces ekonomiczny w coraz większej mierze wynika z tego, iż docenia się należycie rolę człowieka i jego zdolności, popiera się jego świadome uczestnictwo, starannie kultywuje wiedzę i pomnaża zasoby informacji, umacnia solidarność.

Wartości te nie są bynajmniej obce nauce i praktyce ekonomicznej, a przyczyniają się do nadania im charakteru w pełni »ludzkiego«. Ekonomia, która nie bierze pod uwagę wymiaru etycznego i nie stara się służyć dobru człowieka — każdego człowieka i całego człowieka — w istocie rzeczy nie zasługuje nawet na miano »ekonomii«, pojmowanej jako rozumne i dobroczynne zarządzanie zasobami materialnymi”.

\section{Literatura}

1. Capodagli B., Jackson L., Metoda Disneya: jak skutecznie wykorzystać tajemnice zarzadzania Disneya do pracy w twojej firmie. K. E. Liber, Warszawa 2002.

2. Collins J. C., Od dobrego do wielkiego. Czynniki trwałego rozwoju i zwycięstwa firm, Jacek Santorski, Wydawnictwa Biznesowe, 2003 (b.m.w.).

3. Covey S.R., 8 nawyk, Rebis, Poznań 2005.

4. Covey S.R., Zasady skutecznego przywództwa, Rebis, Poznań 2004.

5. Huntsman J. M., Zwycięzcy nie oszukuja, Wydawnictwo Helion, Gliwice 2005.

\section{Moral Values as a Foundation of the True Success of a Manager}

The goal of this text is to focus on the values that are the basis for the true success of a manager. Authors use purposefully the term ,true success" because the word „success" - in relation to a manager or a company - is linked with financial success manifested itself as a growth of personal income and promotion or an increase company's income and profit. Such a success is not satisfied and it often is unstable. True success is founded on moral values and achieved by skilled and courageous persons who also are honest and decent. Their goal is not only financial one, that justify using of immoral means, but they respect universal ethical values. Managers following the rules and achieving the true success feel fulfilled both in personal life and business, they see a sense of life, they know their priorities, and that is why they strike the balance between satisfied family life and personal happiness and the career.

Authors try to answer to the question: what values should guide a manager? What rules should be followed to succeed? Authors appoint these among many moral principles which are the most important in management: honesty, candour, loyalty, modesty, humility, readiness to sharing, friendly cooperation, carefulness, openness, confidence in people and courage. Great managers say that these values are essential to true success. Also scientific research confirms importance of these values. 